Open Access

\title{
The impact of psychological capital on project success mediating role of emotional intelligence in construction organizations of Pakistan
}

\author{
Huma Sarwar ${ }^{1}$, Kashif Nadeem ${ }^{2}$ and Junaid Aftab $^{1 *}$ (D)
}

\author{
* Correspondence: \\ Junaidaftab@rocketmail.com \\ ${ }^{1}$ Management Sciences, COMSATS \\ Institute of Information Technology, \\ Islamabad, Pakistan \\ Full list of author information is \\ available at the end of the article
}

\begin{abstract}
The aspect of emotional intelligence towards psychological capital is still not perfectly and adequately certified and is awaited for further analysis and investigation. Similarly, the growing interest on psychological capital within the managerial literature is rarely researched in Pakistan context. The current study aims to examine the mediating effect of emotional intelligence in the relationship between psychological capital and project success. Main focus is on how employees of construction organizations use their psychological strengths to accomplish their professional objectives. Sample of 213 respondents from 45 construction companies was collected from all over the Pakistan. The findings of the research revealed that psychological capital has significant relationship with emotional intelligence and emotional intelligence has also positive relationship with project success. Emotional intelligence mediated the relationship between three dimensions of psychological capital (self-efficacy, resilience and optimism) and project success whereas no mediation found between hope and project success. The results also indicated that three dimensions of psychological capital (self-efficacy, optimism and resilience) have positive significant relationship with project success and significant mediating effect of emotional intelligence.
\end{abstract}

Keywords: Emotional intelligence, Hope, Resilience, Optimism, Self-efficacy

\section{Background}

Today psychological capital (PsyCap) has become the key component of organizations and has been viewed as strategic resources for the competitive advantage. It is found one of the important management approaches contributes in attaining the highest levels of profitability. Although the concept of "psychological capital" and its dimension has been discussed in various management, clinical and sports sciences but this study attempted to extend this concept with project management. Based on the idea of positive psychology Seligman and Csikszentmihalyi (2000), the construct of psychological capital was first introduced and advanced by Luthans in 2002. It is different from human capital that is what you are, social capital that is who you know.

Psychological capital comprises a set of positive psychological capacities these are hope, self-efficacy, resilience, and optimism (Luthans et al. 2007, b). The main focus of

(c) The Author(s). 2017 Open Access This article is distributed under the terms of the Creative Commons Attribution 4.0 International License (http://creativecommons.org/licenses/by/4.0/), which permits unrestricted use, distribution, and reproduction in any medium, provided you give appropriate credit to the original author(s) and the source, provide a link to the Creative Commons license, and indicate if changes were made. 
psychological capital (PsyCap) shows the same characteristics among the four dimensions and has both empirical (Luthans et al. 2007, b) and conceptual support (Luthans et al. 2007, b; Luthans and Youssef 2004; Luthans and Youssef 2004). Due to increased vacuum and competitiveness in the enthusiasm of feelings among people, it becomes necessary to study and strengthen the psychology of employees to cope the changing workplace settings. 1. Earlier studies reported the fact that PsyCap helps employees of the organizations to complete the project within time and they are observed to be satisfied with their current work environment (Luthans and Youssef 2004; Luthans and Jensen 2002; Wright et al. 2007; Wright 2003).

On the other hand, business managers have realized that to remain in today's competitive global world, they need employees who are academically sound as well as emotionally intelligent. Previously, many researchers and academics have associated project with emotional intelligence (EI) (Salovey et al. 2002; Fredrickson 2003; O'Boyle et al. 2011). It is proved by these studies that emotional intelligence is a dynamic and influential tool for project employees to enhance their interpersonal and intrapersonal performance, capability and effectiveness at workplace. The effect of EI on project success and performance in an organizational environment is still imperfectly confirmed and is awaited for investigation (Mayer 2006; Jena and Pradhan 2015). This study attempted to integrate the psychological capital (PsyCap), emotional intelligence and project success. Emotional intelligence is set to mediate the relationship and association between psychological capital and project success in construction organizations of Pakistan. In developed as well as under developed countries of the world, construction industry is considered to be one of the most crucial industries in terms of contributing in country's GDP and also in the success of mega projects. There are hundreds of renowned construction companies working in Pakistan and we can see the magnificent development in this industry than the earlier days. If these organizations are supported with full potential then they can help the native industries to come up with flying colors. Researchers have chosen 45 major construction organizations of Pakistan. The significance of the major activities that are involved in the construction projects of Pakistan can never be ignored as these activities play a great role in the project success. Project success is one of the distinct areas in the construction industry that requires the attention of many researchers and academicians. It is also an escalating competitiveness of job market which forces the researchers to work in this industry. Construction organizations are increasing significantly in Pakistan and as a result of its rising number of complex and sophisticated projects need competent research. To fulfill the requirements, this research has been done in an appropriate way. According to Ofori (1990), this industry is based on the nature of the projects that a company needs to be completed and qualities of the industry product which clearly illustrates what is included in the construction industry.

According to the best of the researcher's knowledge, there is no prior study exists or has been conducted which combines the variables of this study. Thus, the main objective of this current research is to explore and analyze the relationship of PsyCap with project success among employees in construction organizations of Pakistan. This research is considered as the first systematic research by its nature because of the unavailability of this research to explore the relationship between psychological capital and project success in construction organizations especially from Pakistan. This study is useful for the construction organizations that if they focus on the development of 
psychological capital then this can be helpful for the project success. Furthermore, emotional intelligence might be work as an important catalyst in the completion of project success. Therefore, in this back drop the current study was planned.

\section{Problem statement}

The construction industry of Pakistan faces many challenges and these firms striving hard to increase the competitive advantage by focusing on emotionally intelligent employees who work effectively and efficiently in stressful situation. In-spite the interest of researchers in the concept of psychological capital, its impact on project success needs to be investigated in construction industry. In this context, the main aim of current study is to investigate the relationship among psychological capital and its impact on success of project with mediation effect of emotional intelligence.

\section{Literature review and theoretical framework}

By following the different inclusion criteria, Luthans and his colleagues identified the four psychological capacities such as hope; self-efficacy, resilience and optimism are considered to be dimensions of psychological capital. The main feature of these dimensions is that these are stat-like and are opened to develop. In the following section, these are discussed in detail.

\section{Hope}

Hope is an important component of psychological capital (PsyCap) and is generally used in our daily life. It is observed to be related with the physical and mental health, athletic performance, academic performance, and the ability to deal with the trouble and distress (Snyder et al. 1991; Curry et al. 1997). According to Peterson and Byron (2008) hope is positively associated with job performance, profitability, leadership, organizational commitment, job satisfaction, work happiness. Harvey et al. (2007) found that the theory of hope comprised of three components those are: Power, Goals and Path. It provides a realism and challenge to achieve the goals (Malone, 2010). Hope is the ability to determine, illuminate and follow the best way to success. Employees with high levels of hope have the capacity to deal with all the situations. Luthans et al. (2008) argued that hopeful individuals have high energy to identify the goal and develop alternative pathways to attain these goals. It is also found that hopeful people are considered as independent thinkers (Luthans et al. 2007). When all the ways are blocked, hopeful and dedicated individuals like to take risks and find different alternative pathways to success (Snyder 1994, 2002).

\section{Self-efficacy}

The concept of self-efficacy is developed by Bandura (1997), based on theory of social cognitive. It was defined as "individuals" opinion and belief about courses of action, motivation and cognitive resources necessary to complete a given task within a specific time and budget (Stajkovic and Luthans 1998). Luthans and Youssef (2004) described the content of the self-efficacy as indirect modeling and experience, performance achievements, mastery experiences, Social convince, physiological and psychological excitement. Luthans et al. (2007b) stated that Self-efficacy fulfilled the inclusion and 
incorporation criteria for PsyCap. Self-efficacy is related with the positive belief and was characterized by the work environment by (Stajkovic and Luthans 1998). They found the self-efficacy as "the worker's belief, persuasion and assurance about his or her capabilities to effectively and efficiently execute a given task within a given time limit." So it is proved that self-efficacy has a significant relationship with performance (Stajkovic and Luthans 1998; Bandura and Locke 2003).

\section{Resilience}

Third positive and important component of psychological capital is resilience. The Theory of resilience is originated from the clinical psychology's work with growing kids that achieve the given targets and succeeded despite risk and hardships. According to Luthans (2002) resilience is the capability of the individuals to get back from uncertainty and failure. According to Masten and Wright (2009), resilience is the process of positive arrangement and modification in the work environment. Individuals with high resilience have the ability to take risk and overcome the risk. So resilient individuals are risk taker (Masten and Reed 2002). They are optimistic and humorous (Wolin and Wolin 1993; Masten 1994). Block and Kremen (1996) stated that employees with resilience are curious and energetic towards life (Klohnen 1996). These individuals are innovative, like new experiences and use creative exploration (Cohler 1987). Kappagoda et al. (2014a) characterized the resilience as "It is a positive force that might be utilized to counter the negative events by adding the extreme positive events". Enzi and Ibrahim (2012) stated the three basis of resilience called (Cs), are: connectedness, coherence and control (Reich, 2006).

\section{Optimism}

The theory of optimism as a positive organizational behavior (POB) is generally originated by Seligman (1998). In particular, optimism is characterized as making stable, global and internal attribution towards achievement of goal and objective and an unstable, external and negative events such as not to fulfill the goals. According to Carver et al. (2005), optimists are those who anticipate that positive things will happen in life. But pessimists are those thinking about the negative things in life. Self-assured person has a feeling that the positive and constructive events and occasions happen as consequence of their own behavior and practices. Optimism is an activity that is related to achieve the target and selfregulation. So, optimist has a sense that positivity comes in reaction to their behavior and actions (Avey et al. 2010). Seligman (1998) stated that the individuals who have positive attitude towards incidents, an internal stability, global attribution and inward steadiness are optimists they are also called task accomplisher and those who behave like unstable, shows negative attitude are pessimist. He also found that optimism is positive significantly associated with sale agent's performance of insurance company. Totterdell et al. (2006) found that the relationship of characteristics and attributes of stress and work is mediated by the optimism. Simarasl et al. (2010), found that it is a common or broad conviction that good and pleasant events occur more than bad events in life.

\section{Psychological capital and project success}

The project based organizations play a key role in forming the Pakistan economy, the success of industries as a service organization depends on the psychological factor, employee's 
performance and their satisfaction. Sustenance and support of an organization depend on various capitals like human, social and economic capital. Human capital refers to people resources; social capital speaks about empathy, feelings interpersonal relationship with fellows. And economic capital comprises of intangible assets. Seligman (2002) in his book "Authentic happiness" explored the existence another need of forth capital i.e. PsyCap which relates to happiness and well-being at workplace. Psychological capital has been emerged by extending the other capitals, such as human capital and social capital. Luthans et al. (2008) observed PsyCap a significant input through gaining positive results in the improvement of job performance and human resources. PsyCap might directly correlate with project success of any organization if traits such as emotional stability, leadership motivation and assertiveness meet the goals and objectives of the employee's role, managing social interactions, enhancing effective leadership and making high and complex impact decisions (Thoresen 2006). Sun et al. (2011) found that PsyCap enhances employee's performance and help in achieving their goals. Another study by Nelson and Cooper (2007) proved that PsyCap is significantly associated with individual performance. This study assumes that dimensions of psychological capital have significantly related to project success, so following hypotheses were drawn:

H1: Hope has effect on project success.

H2: Self-efficacy has effect on project success.

H3: Resilience has effect on project success.

H4: Optimism has effect on project success.

\section{Psychological capital and emotional intelligence}

Initially, the term "social intelligence" was introduced by Thorndike (1920) in the start of twentieth century which later on turned into emotional intelligence (EI). US analysts John Mayer and Peter Salovey then used the term Emotional Intelligence in 1990. They characterized EI as the "capacity to feel, to get to and create feelings in order to help thought, to comprehend feelings and passionate implications, and to brilliantly manage feelings in ways that advance enthusiastic and scholarly development". The best services are only delivered through the employees in organizations and help in enhancing the overall performance of the organizations. The concept of psychological capital has been growing great interest in recent years to promote employee's performance that leads to the project success (Kappagoda et al. 2014a). Luthans and Youssef (2007) has defined this term as "an individual's better psychological situation of success". In project based environment, employee's performance is lynchpin among the central compositions that play a major role in attainment of organizational goals. Pradhan and Jena (2016) stated that employees are able to handle their requirements at ease those hold high emotional intelligence. Carmeli (2003) observed that employees are more engaged in high-role behavior which have high emotional intelligence and in turn they demonstrate better performance and high profitability. Martinez (1997) referred emotional intelligence as a set of competencies, capabilities that impacts employee's ability to handle the varied organizational demands and pressures. Research work of Luthans et al. (2007b) about the PsyCap has explained that PsyCap is a higher order factor that leads to higher organizational performance. A lot of previous studies have examined the outcomes of psychological capital related to employees that are: employee performance, 
attitude and behavior (Avey et al. 2010). Sahoo and Sia (2015) have explored the impact of PsyCap at organizational levels. Pradhan and Jena (2016) proposed that highly emotionally intelligent employees have ability to handle any problem with ease.

In the previous literature, emotional intelligence has been studied as mediator variable in several fields, such as health sciences, psychology and organizational settings etc. A study by Irshad and Hashmi (2014) has found that emotional intelligence mediates the relationship of transformational leadership and organizational citizenship behavior among the banking sector employees working in Pakistan. Schutte and Malouff (2011) reported that emotional intelligence acts as a mediator between the relationship of mindfulness and subjective well-being (lower negative affect, higher positive affect, and greater life satisfaction). Similarly, Wang and Kong (2014) have reported that emotional intelligence partially mediated influence of mindfulness on mental distress and life satisfaction among Chinese adults.

In a separate study, Keaten and Kelly (2008) found that emotional intelligence plays a mediator role between the relationship of family communication pattern (conversation orientation) and reticence. Likewise, Silter et al. (2013) reported that emotional intelligence partially mediates the relationship of age and emotional labor strategies (surface and deep acting) among the service employees. A recent study concluded that emotional intelligence partially mediates the relationship between the anxious insecurity and health outcomes, whereas fully mediates the association among avoidant insecurity and health outcomes (Marks et al. 2016).

According to the researcher's knowledge, no prior study has investigated the mediation role emotional intelligence among the relationship of psychological capital (hope, self-efficacy, resilience and optimism) and project success, so, this current study examines mediating role of emotional intelligence among the relationship of psychological capital (hope, self-efficacy, resilience and optimism) and project success among construction sector employees in Pakistan.

For this, following hypotheses were drawn:

H5: Emotional intelligence mediates the relationship between hope and project success.

H6: Emotional intelligence mediates the relationship between self-efficacy and project success.

H7: Emotional intelligence mediates the relationship between resilience and project success.

H8: Emotional intelligence mediates the relationship between optimism and project success (Fig. 1).

\section{Methods}

The research was related to construction industry of Pakistan or more specifically it was related to the leader/professionals working in the construction industry of Pakistan. So, it shows the unit of analysis of the research is professionals and stake holders linked with construction industry. Data collected through questionnaires which were designed in such a way to get the desire information. Close ended questions of 5 points Likert scale were used to acquire data about respondent's level of affirmation to investigate and uncover the effect of psychological factors on project success. Structured questionnaire has been developed to collect data from respondents. A questionnaire having all measurement scales were distributed to 500 employees of construction organizations. 


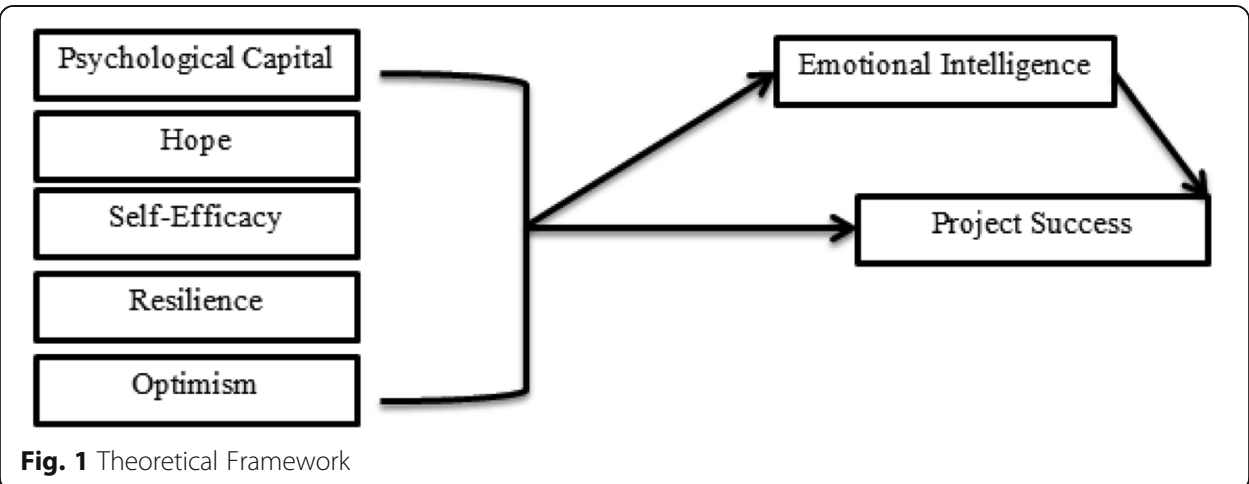

Two hundred and thirteen questionnaires were received with almost $43 \%$ response rate which was completed in all aspects. The percentages of male respondents were $76 \%$ and female respondents were $24 \%$. The percentage of age groups i.e. almost $4 \%$ in the range of less than 25 years, $54 \%$ between age group of 26 and 40 years, 33\% between 41 and 55 years and finally $9 \%$ in the group of 56 and above. Similarly, on the basis of the province $34 \%$ of the sample belongs to Punjab, $15 \%$ of belongs to Sindh, respondents belong to Balochistan, KPK, Gilgit Baltistan and Azad Kashmir were 16, 17, 10 and $8 \%$ respectively.

\section{Measurement of scales}

To measure the project success, a scale developed by (Aga et al. 2016) having 13 items was used in this study. These 13 items scale demonstrated adequate internal reliability with 0.896. Emotional Intelligence was measured with 13 items established by (Schutte et al. 1998). Psychological capital was measured thorough the 24 items instrument developed by Luthans et al. (2007b). Psychological capital comprises on four dimensions that includes hope, efficacy, resilience and optimism. This instrument of psychological capital includes 6 items for each of these four dimensions. All four instruments of PsyCap scale demonstrated adequate internal reliability as $\alpha$ greater than 0.7 (Table 1).

\section{Data analysis}

Structural equation modeling (SEM) was used to measure interrelationship among variables. IBM AMOS Version 22 was utilized to analyze the collected data. It is known as more flexible and reliable statistical tool than others. According to Holmes-Smith et al. (2004), SEM allows for simultaneous multiple dependent relationships between the variables.

Table 1 Cronbach's Alpha

\begin{tabular}{lll}
\hline Variables & Items & Cronbach's a \\
\hline Hope & 06 & .732 \\
Self-efficacy & 06 & .831 \\
Resilience & 06 & .846 \\
Optimism & 06 & .793 \\
Emotional Intelligence & 13 & .866 \\
Project Success & 13 & .896 \\
\hline
\end{tabular}




\section{Results and discussion}

\section{Correlations}

The mean, standard deviations and correlation among independent, dependent and mediating variables are presented in Table 2. The correlation Table 2 shows that all variables are significantly correlated with project success. Emotional intelligence has positive correlation with project success (coefficient $=0.383, p<0.01$ ). All dimensions of psychological capital (Hope, Self-efficacy, Optimism and resilience) also have positive relationship with project success (coefficient $=0.432, p<0.01$ ), (coefficient $=0.425, p<0.01$ ), (coefficient $=0.427, p<0.01$ ) and (coefficient $=0.302, p<0.01$ ) respectively, which justifies the hypothesis of current study.

The correlation coefficients of these variables are below the cut off value of 0.75 . So, there is no problem of multicollinearity found among independent variables.

\section{Confirmatory factor analysis}

Gerbing and Anderson (1988) highlighted the significance of uni-dimensionality in the validation process of scales used in the analysis. They pointed out that traditional EFA is not theory based analysis so it fails to assess uni-dimensionality and measurement model fit of the scales initially. To overwhelm this limitation, CFA was employed for the assessment of measurement model fit and uni-dimensionality. $\mathrm{Hu}$ and Bentler (1999) observed from different studies that good fitting models should have a value of .95 or greater for CFI, GFI, NFI, TLI or greater, the value of (RMSEA) equal to or less than .06. Table 3 presented the model fitness of CFA model which was examined through model fitness ratios prescribed by various researchers. Initial model has produced following fitness ratios such as CMIN/DF $=1.930$, GFI $=.778, \mathrm{CFI}=.875$, $\mathrm{NFI}=.776$. All these ratios indicated that model is poor fit with data.

So after modification in the initial model following are the model fitness ratios which indicate that model is good fit for further analysis. Which are reproduced in following Table 4, for the factor loading, those items having factor loading less than .40 were deleted from the final analysis. It has been examined that 2 item of emotional intelligence, 2 items of project success and 1 item of PsyCap was removed due to less factor loading $<0.40$ and all ratios such as CMIN/DF, GFI, CFI, NFI and RMSEA shows good model fitness. Value of CMIN/DF is supposed as measure of model fitness. According to Marsh et al. (1985) for good model fitness value, the CMIN/DF should be less than 5. It is observed that model B is reasonably fit for data analysis.

Table 2 Correlations

\begin{tabular}{lllllllll}
\hline Variables & Mean & STD & PS & El & Hope & Efficacy & Resilience & Optimism \\
\hline PS & 3.58 & .65 & 1.000 & & & & & \\
El & 3.76 & .68 & $.383^{\mathrm{a}}$ & 1.000 & & & & \\
Hope & 3.73 & .76 & $.432^{\mathrm{a}}$ & $.631^{\mathrm{a}}$ & 1.000 & & & \\
Efficacy & 3.58 & .73 & $.425^{\mathrm{a}}$ & $.502^{\mathrm{a}}$ & $.575^{\mathrm{a}}$ & 1.000 & & \\
Resilience & 3.77 & .89 & $.306^{\mathrm{a}}$ & $.389^{\mathrm{a}}$ & $.634^{\mathrm{a}}$ & $.575^{\mathrm{a}}$ & 1.000 & \\
Optimism & 3.22 & .45 & $.427^{\mathrm{a}}$ & .125 & $.595^{\mathrm{a}}$ & $.510^{\mathrm{a}}$ & $.566^{\mathrm{a}}$ & 1.000 \\
\hline
\end{tabular}

PS project success, El emotional intelligence

${ }^{a}$ Correlation is significant at the 0.01 level (2-tailed) 
Table 3 Fitness Ratio of Initial Model

\begin{tabular}{lllllll}
\hline & CMIN & CMIN/DF & GFI & NFI & CFI & RMSEA \\
\hline Model A & 1277.95 & 1.930 & .778 & .776 & .875 & .066 \\
\hline
\end{tabular}

\section{Structural equation modeling}

A structure equation modeling of psychological capital, emotional intelligence and project success were conducted to estimate the parameters. This SEM technique is supposed to be a more acceptable than stepwise regression techniques because in this technique all mediation paths of variables were measured simultaneously. In current study the data showed strong model fitness with different ratio's values of NFI $=.943$, $\mathrm{CFI}=.985, \mathrm{GFI}=.958 \mathrm{RMSEA}=.049$ and $\mathrm{CMIN} / \mathrm{DF}=2.004$ (Fig. 2).

Hypothesis 1 predicted that hope is not significantly related to project success $(\beta=.10, p$-value $>0.01)$ It is evident from Fig. 2 that this hypothesis was rejected because hope was not significantly related to the project success. Hypothesis 2 predicted that self-efficacy has a positive relationship to the project success and it is concluded that self-efficacy is significantly associated to project success $(\beta=.42, p$-value $<0.01)$. This direct relationship between self-efficacy and project success was supported and $\mathrm{H} 2$ was accepted as shown in Fig. 2.

In the third hypothesis, resilience is found to have positive significant effects on project success $(\beta=.35, p$-value $<0.01)$ thus hypothesis 3 is accepted. While the Hypothesis 4 predicted that optimism is positively related to project success and the findings proved this hypothesis as $(\beta=.31, p$-value $<0.01)$. So, hypothesis 4 is accepted.

To analyze the mediating effects of emotional intelligence, current study investigated and verified both the direct effect of emotional intelligence on self-efficacy, hope, resilience and optimism and its indirect effect related to mediating of emotional intelligence are significant. It was proved that hope does not affect project success significantly both directly $(\beta=.10, p$-value $>0.01)$ and indirectly $(\beta=.35 p$-value $>0.01)$, Thus, there is no mediation of emotional intelligence found between project success and hope and hypothesis 5 is rejected.

Hypothesis 6 predicted that emotional intelligence (EI) mediate the association between self-efficacy and project success. It was concluded from the analysis that selfefficacy effects project success significantly both directly $(\beta=.42, p$-value $<0.01)$ and indirectly $\left(\beta=.40^{* *}, p\right.$-value $\left.<0.01\right)$ and $(\beta=.36, p$-value $<0.01)$ respectively. It proved that hypothesis 6 is accepted and partial mediation was found between EI, self-efficacy and project success.

The results for hypothesis 7 confirm that emotional intelligence mediates the relationship between resilience and project success. Resilience effects project success significantly both directly $\left(\beta=.35^{* * *}, p\right.$-value $\left.<0.01\right)$ and indirectly $(\beta=.22, p$-value $<0.01)$, $(\beta=.36, p$-value $<0.01)$ respectively. It showed the partial mediation of EI with resilience and project success. In the final hypothesis 8 , we predicted that emotional intelligence partially mediated the association between Optimistic and project success. Optimism effects project success significantly both directly $\left(\beta=.31^{* * *}, p\right.$-value $\left.<0.01\right)$

Table 4 Fitness Ratio of Modified Model

\begin{tabular}{lllllll}
\hline & CMIN & CMIN/DF & GFI & NFI & CFI & RMSEA \\
\hline Model B & 1637.41 & 2.004 & .958 & .943 & .985 & .049 \\
\hline
\end{tabular}




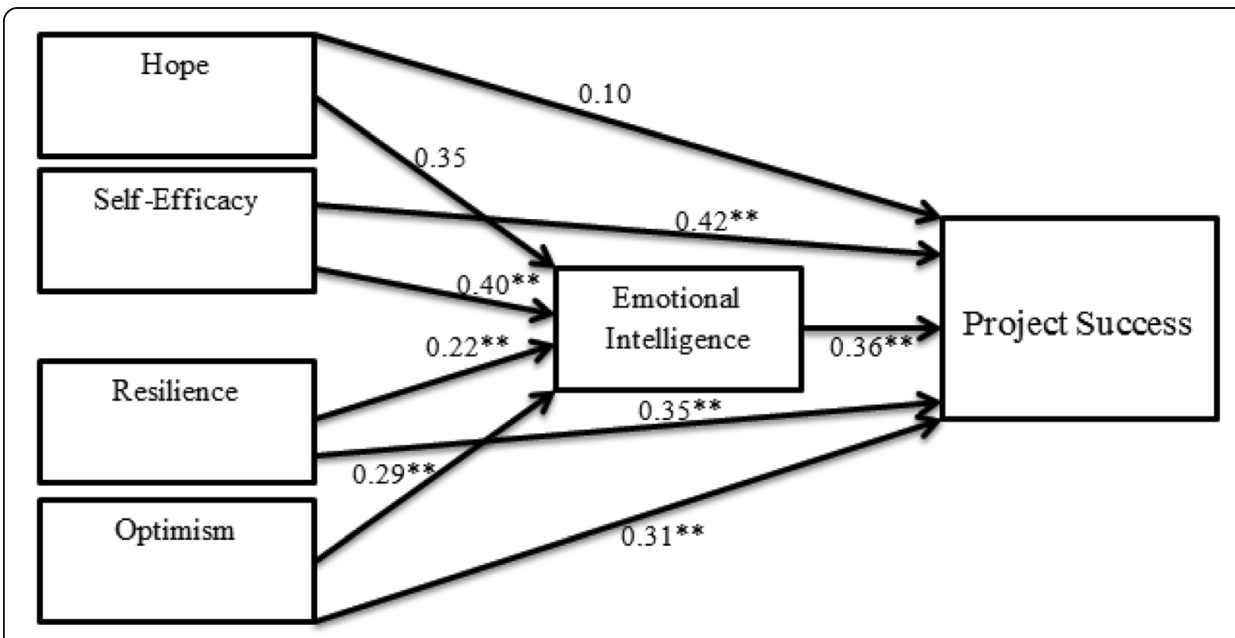

Fig. 2 Structural Equation Model. ** Significant at 0.01 level

and indirectly $(\beta=.29, p$-value $<0.01),(\beta=.36, p$-value $<0.01)$ respectively. As shown in Fig. 2, optimism, resilience and self-efficacy were significantly related with the mediating variable emotional intelligence, and emotional intelligence was significantly associated to the dependent variable project success. Thus the findings support study hypotheses and partial mediation of emotional intelligence was found between the dimensions of psychological capital (self-efficacy, resilience and optimism).

As there is no prior study exists which combines the psychological capital and project success and shows their relationship with the mediation of emotional intelligence; so. there is no literature found to cite with the results of this research.

The main aim of current study was to carry out an empirical exploration of association between hope, resilience, efficacy, optimism with project success and the mediating effect of emotional intelligence on all the dimensions of psychological capital and project success among the employees of construction organizations of Pakistan. This study proved that the psychological capital affects successful completion of the project in any organization and emotional intelligence (EI) is also very important factor for the project success. It is concluded that if organizations invest more on the psychological capital can get the more benefits than the organizations do not invest on the psychological capital. So, psychological capital and emotional intelligence have become a crucial element in the construction organizations of Pakistan. Construction organizations should focus on self-efficacy, optimism and resilience to get the desired results. The significance of this research including the factors behind the project success and the requirements of the competitive world find the necessity to pay attention to the importance of psychological capital and emotional intelligence. Therefore, it can be suggested to HR managers to pay attention on the dimensions of PsyCap (hope, self-efficacy, resilience and optimism) and include EI constructs as a component in their daily practices to improve the capability and performance of employees for project success.

\section{Conclusion}

Now-a-days, psychological capital plays an important part in success of any project specifically in construction industry. It is also noted that leaders who have high emotional 
intelligence can often lead their projects toward success and effect the psychological capital also. The main objective of current study was to examine the role of psychological capital and its implication on project success while emotional intelligence mediating the effect between them in the construction organizations of Pakistan. The results depicted that there is strong association exists among all three variables and three dimensions (self-efficacy, resilience and optimism) of psychological capital significant relationship with project success except $\mathrm{H}_{1}$ where there is no significant relationship exists between hope and project success. Similarly, the results of mediation showed that there is partial mediation exist between psychological capital dimensions (self-efficacy optimism and resilience) and project success. While result of $\mathrm{H}_{5}$ does not support our claim that there is mediation of emotional intelligence exist between hope and project success. The outcomes of this study would be helpful for the upper management to create an environment in which the employee feels high sense of optimism, hope, selfefficacy and resilience. When the individuals feel positive about psychological capital than it increased their performance and hence it helps the organizations to make the project successful. Also, emotional intelligence of leaders/managers plays a vital role to achieve the psychological capital.

\section{Limitations and future research}

The results of this research are not universal. The present study was limited to public and private construction organizations of Pakistan. So, the results might not be helpful for other construction organizations which operate demographically in different countries and cultures than Pakistan. Thus, future study might increase the sample size by collecting data from different countries to make the outcomes more universal and helpful for other international construction organizations.

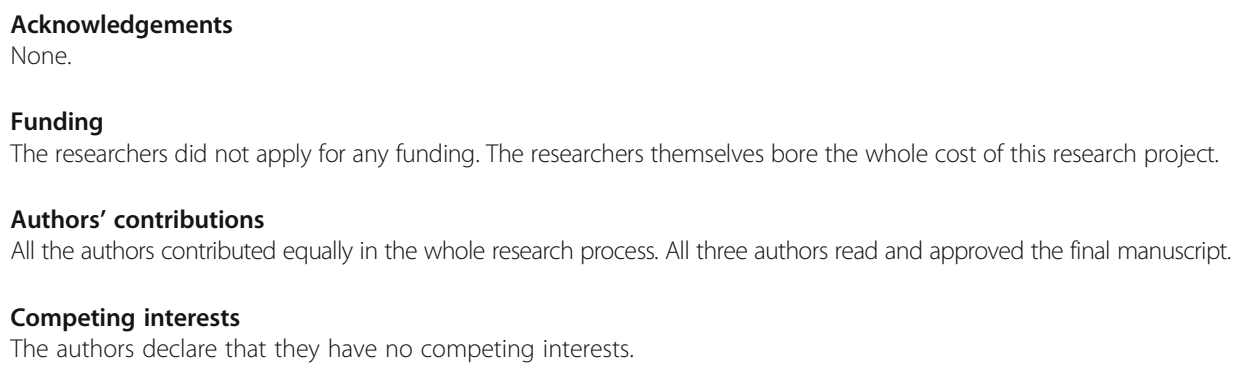


Block, J., \& Kremen, A. M. (1996). IQ and ego-resiliency: conceptual and empirical connections and separateness. Journal of Personality and Social Psychology, 70(2), 349.

Carmeli, A. (2003). The relationship between emotional intelligence and work attitudes, behavior and outcomes: An examination among senior managers. Journal of Managerial Psychology, 18(8), 788-813.

Carver, C. S., Smith, R. G., Antoni, M. H., Petronis, V. M., Weiss, S., \& Derhagopian, R. P. (2005). Optimistic personality and psychosocial well-being during treatment predict psychosocial well-being among long-term survivors of breast cancer. Health Psychology, 24(5), 508.

Cohler, B. J. (1987). Adversity, resilience, and the study of lives. In The invulnerable child (pp. 363-424).

Curry, L. A., Snyder, C. R., Cook, D. L., Ruby, B. C., \& Rehm, M. (1997). Role of hope in academic and sport achievement. Journal of Personality and Social Psychology, 73(6), 1257.

Enzi, S., Ibrahim, I. (2012), Positive psychological capital (PSYCAP) (conceptual perspective in core basics and requirements for building and preparing. Journal of Economic and Administrative Sciences,18(65), 1-31.

Fredrickson, B. L. (2003). Positive emotions and upward spirals in organizations. In Positive organizational scholarship (pp. 163-175).

Gerbing, D. W., \& Anderson, J. C. (1988). An updated paradigm for scale development incorporating unidimensionality and its assessment. Journal of Marketing Research, 186-192.

Harvey, M., Novicevic, M., \& Breland, J. (2007). Global dual-career exploration and the role of hope and curiosity during the process. Journal of Managerial Psychology, 42(2), 178-197.

Holmes-Smith, P., Coote, G. L., \& Cunningham, E. (2004). Structural equation modelling: From the fundamentals to the advanced topics. Victoria, Australia: School Research, Evaluation, and Measurement Services.

Hu, L. T., \& Bentler, P. M. (1999). Cutoff criteria for fit indexes in covariance structure analysis: Conventional criteria versus new alternatives. Structural Equation Modeling: A Multidisciplinary Journal, 6(1), 1-55.

Irshad, R., \& Hashmi, M. S. (2014). How Transformational Leadership is related to Organizational Citizenship Behavior? The Mediating Role of Emotional Intelligence. Pakistan Journal of Commerce and Social Sciences, 8(2), 413-425.

Jena, L. K., \& Pradhan, R. K. (2015). Psychological capital and workplace spirituality: Role of emotional intelligence. International Journal of Work Organisation and Emotion, 7(1), 1-15.

Kappagoda, S., Othman, P., Fithri, H. Z., \& Alwis, G. D. (2014). The impact of psychological capital on job performance: Development of a conceptual framework. Dr. Hohd. Zainul Fithri and Alwis, Gamini De, The Impact of Psychological Capital on Job Performance: Development of a Conceptual Framework (June 1, 2014). European Journal of Business and Management.

Keaten, J., \& Kelly, L. (2008). Emotional Intelligence as as Mediator of Family Communication Patterns and Reticence. Jounal of communication reports, 21(2), 104-116.

Klohnen, E. C. (1996). Conceptual analysis and measurement of the construct of ego-resiliency. Journal of Personality and Social Psychology, 70(5), 1067.

Luthans, F. (2002). Positive organizational behavior: Developing and managing psychological strengths. The Academy of Management Executive, 16(1), 57-72.

Luthans, F., Avolio, B. J., Avey, J. B., \& Norman, S. M. (2007). Positive psychological capital: Measurement and relationship with performance and satisfaction. Personnel Psychology, 60(3), 541-572.

Luthans, F., \& Jensen, S. (2002). Hope: A new positive strength for human resource development. Human Resource Development Review, 1(3), 304-322.

Luthans, F., Norman, S. M., Avolio, B. J., \& Avey, J. B. (2008). The mediating role of psychological capital in the supportive organizational climate-employee performance relationship. Journal of Organizational Behavior, 29(2), 219-238.

Luthans, F., \& Youssef, C. M. (2004). Human, social, and now positive psychological capital management:: Investing in people for competitive advantage. Organizational Dynamics, 33(2), 143-160.

Luthans, F., \& Youssef, C. M. (2007). Emerging positive organizational behavior. Journal of Management, 33(3), 321-349.

Luthans, F., Youssef, C. M., \& Avolio, B. J. (2007). Psychological capital: Developing the human competitive edge (p. 3). Oxford: Oxford University Press.

Malone, L. (2010). Individual Differences and Stress Reactions as Predictors of Performance in Pilot Trainees, Master Thesis. Manhattan, Kansas: Kansas State University.

Marks, A. D. G., Horrocks, K. A., \& Schutte, N. S. (2016). Emotional Intelligence mediates the relationship between insecure attachement and subjective Health outcomes. Personality and Individual Differences, 98, 188-192.

Marsh, H. W., Barnes, J., \& Hocevar, D. (1985). Self-other agreement on multidimensional self-concept ratings: Factor analysis and multitrait-multimethod analysis. Journal of Personality and Social Psychology, 49(5), 1360.

Martinez, M. N. (1997). The Smarts That Count: Even rocket scientists need to develop their Emotional Intelligence if they want to soar to new performance heights. HR magazine, 42, 72-79.

Masten, A. S. (1994). Resilience in individual development: Successful adaptation despite risk and adversity.

Masten, A. S., \& Reed, M. J. (2002). Resilience in development. In C. R. Snyder \& S. J. López (Eds.), Handbook of positive psychology (pp. 74-88).

Masten, W., \& Wright, M. O. (2009). Resilience over the lifespan. Handbook of adult resilience, 213-237.

Mayer, J. D. (2006). A new field guide to emotional intelligence. In J. Ciarrochi, J. P. Forgas, \& J. D. Mayer (Eds.), Emotional intelligence in everyday life (2nd ed., pp. 3-26). New York: Psychology Press.

Nelson, D., \& Cooper, C. (2007). Positive Organizational Behavior: Accentuating the Positive at Work. Thousand Oaks: Sage.

O'Boyle, E. H., Humphrey, R. H., Pollack, J. M., Hawver, T. H., \& Story, P. A. (2011). The relation between emotional intelligence and job performance: A meta-analysis. Journal of Organizational Behavior, 32(5), 788-818.

Ofori, G. (1990). The construction industry: aspects of its economics and management. NUS Press.

Peterson, S. J., \& Byron, K. (2008). Exploring the role of hope in job performance: Results from four studies. Journal of Organizational Behavior, 29(6), 785-803.

Pradhan, R. K., \& Jena, L. K. (2016). Workplace spirituality and organisational commitment: Role of emotional intelligence among Indian banking professionals. Journal of Human Resource Management, 19(1), 13-23. 
Reich, J. W. (2006). Three psychological principles of resilience in natural disasters. Disaster Prevention and Management: An International Journal, 15(5), 793-798.

Sahoo, B. C., \& Sia, S. K. (2015). Psychological capital and organizational commitment: Nature, structure and relationship in an Indian sample. Asia Pacific Journal of Management Research and Innovation, 11, 230-244.

Salovey, P., Mayer, J. D., \& Caruso, D. R. (2002). The positive psychology of emotional intelligence. In C. R. Snyder \& S. J. Lopez (Eds.), Handbook of positive psychology (pp. 159-171). New York: Oxford University Press.

Schutte, N. S., Malouff, J. M., Hall, L. E., Haggerty, D. J., Cooper, J. T., Golden, C. J., \& Dornheim, L. (1998). Development and validation of a measure of emotional intelligence. Personality and Individual Differences, 25(2), 167-177.

Schutte, N. S., \& Malouff, M. (2011). Emotional Inelligene mediates the relationship between mindfulness and subjective well-being. Journal of personality and individual differences, 5(7), 1116-1119.

Seligman, M. E. (1998). What is the good life. APA monitor, 29(10), 2.

Seligman, M. E. (2002). Authentic happiness. New York: Atria.

Seligman, M. E., \& Csikszentmihalyi, M. (2000). Special issue on happiness, excellence, and optimal human functioning. American Psychologist, 55(1), 5-183.

Silter, M., Chen, Y., Withrow, S., \& Silter, K. (2013). Older and (Emotionally) Smarter? Emotional Intelligence as a Mediator in the Relationship between Age and Emotional Labor Strategies in Service Employees. Journal of Experimental Aging Research, 39(4), 466-479.

Simarasl, N., Fayazi, M., \& Gholipour, A. (2010). Explanation of the Consequences of Positive Organizational Behavior (POB) Among Iranian Librerians. FasInameye oloume modireyate iran, 5(17), 23-45.

Snyder, C. R. (1994). The psychology of hope: You can get there from here. Chicago: Simon and Schuster.

Snyder, C. R. (2002). Hope theory: Rainbows in the mind. Psychological Inquiry, 13(4), 249-275.

Snyder, C. R., Irving, L. M., \& Anderson, J. R. (1991). Hope and health. Handbook of social and clinical psychology: The health perspective, 162, 285-305.

Stajkovic, A. D., \& Luthans, F. (1998). Self-efficacy and work-related performance: A meta-analysis. Psychological Bulletin, 124(2), 240

Sun, T., Zhao, X., Yang, L., \& Fan, L. (2011). The Impact of Psychological Capital on Job Embeddedness and Job Performance among Nurses: A Structural Equation Approach. Journal of Advanced Nursing, 68(1), 69-79.

Thoresen, B. (2006). Empty promises. Management Review, 85, 16-23.

Thorndike, E. L. (1920). Intelligence and its uses. Harper's Magazine, 140, 227-235.

Totterdell, P., Wood, S., \& Wall, T. (2006). An intra-individual test of the demands-control model: A weekly diary study of psychological strain in portfolio workers. Journal of Occupational and Organizational Psychology, 79(1), 63-84.

Wang, Y., \& Kong, F. (2014). The Role of Emotional Intelligence in the impact of Mindfulness on Life Satisfaction and Mental Distress. Social Indicators Research, 116(3), 8443-8852.

Wolin, S. J., \& Wolin, S. (1993). Bound and determined: Growing up resilient in a troubled family.

Wright, T. A., Cropanzano, R., \& Bonett, D. G. (2007). The moderating role of employee positive well-being on the relation between job satisfaction and job performance. Journal of Occupational Health Psychology, 12(2), 93.

Wright, T. A. (2003). Positive organizational behavior: An idea whose time has truly come. Journal of Organizational Behavior, 24(4), 437-442.

\section{Submit your manuscript to a SpringerOpen ${ }^{\circ}$} journal and benefit from:

- Convenient online submission

- Rigorous peer review

- Open access: articles freely available online

- High visibility within the field

- Retaining the copyright to your article 